\title{
On the Interplay Between Microstructure and Interfaces in High-Efficiency Microcrystalline Silicon Solar Cells
}

\author{
Simon Hänni, Duncan T. L. Alexander, Laura Ding, Grégory Bugnon, Mathieu Boccard, Corsin Battaglia, \\ Peter Cuony, Jordi Escarré, Gaetano Parascandolo, Sylvain Nicolay, Marco Cantoni, Matthieu Despeisse, \\ Fanny Meillaud, and Christophe Ballif
}

\begin{abstract}
This paper gives new insights into the role of both the microstructure and the interfaces in microcrystalline silicon $(\mu \mathrm{c}$ Si) single-junction solar cells. A 3-D tomographic reconstruction of a $\mu \mathrm{c}-\mathrm{Si}$ solar cell reveals the 2-D nature of the porous zones, which can be present within the absorber layer. Tomography thus appears as a valuable technique to provide insights into the $\mu \mathrm{c}$ Si microstructure. Variable illumination measurements enable to study the negative impact of such porous zones on solar cells performance. The influence of such defective material can be mitigated by suitable cell design, as discussed here. Finally, a hydrogen plasma cell post-deposition treatment is demonstrated to improve solar cells performance, especially on rough superstrates, enabling us to reach an outstanding $10.9 \%$ efficiency microcrystalline singlejunction solar cell.
\end{abstract}

Index Terms-High efficiency, microcrystalline silicon ( $\mu \mathrm{c}-\mathrm{Si})$, thin-film solar cells, tomography.

\section{INTRODUCTION}

M ICROCRYSTALLINE silicon $(\mu \mathrm{c}-\mathrm{Si})$ is a material which is now commonly used in thin-film photovoltaics and which could lead, with amorphous silicon in the tandem configuration, to module production costs as low as $0.5 \$ / \mathrm{W}_{\mathrm{p}}$ in a close future, even at moderate production volume [1]. Indeed, its good stability against light soaking and its extended absorption in the 800-1100-nm range of the solar spectrum com-

Manuscript received May 25, 2012; revised July 30, 2012; accepted August 9 , 2012. Date of publication September 13, 2012; date of current version December 19, 2012. This work was supported in part by Competence Center Energy and Mobility and Swisselectric Research (DURSOL project, www.dursol.ch), by the Swiss Federal Office of Energy under Project 101191, and by the FP7 project "Fast Track," funded by the European Commission under Grant 283501.

S. Hänni, L. Ding, G. Bugnon, M. Boccard, C. Battaglia, P. Cuony, J. Escarré, G. Parascandolo, S. Nicolay, M. Despeisse, F. Meillaud, and C. Ballif are with the Laboratory of Photovoltaics and Thin Film Electronics, Institute of Microengineering, Ecole Polytechnique Fédérale de Lausanne, CH-2000 Neuchâtel, Switzerland (e-mail: simon.haenni@epfl.ch; laura.ding@epfl.ch; gregory.bugnon@epfl.ch; mathieu.boccard@epfl.ch; corsin.battaglia@epfl.ch; peter.cuony@epfl.ch; jordi.escarre@epfl.ch; gaetano.parascandolo@epfl.ch; sylvain.nicolay@epfl.ch; matthieu.despeisse@epfl.ch; fanny.sculati-meillaud@ epfl.ch; christophe.ballif@epfl.ch).

D. T. L. Alexander and M. Cantoni are with the Interdisciplinary Centre for Electron Microscopy, Ecole Polytechnique Fédérale de Lausanne, CH-1015 Lausanne, Switzerland (e-mail: duncan.alexander@epfl.ch; marco.cantoni@epfl.ch).

Color versions of one or more of the figures in this paper are available online at http://ieeexplore.ieee.org.

Digital Object Identifier 10.1109/JPHOTOV.2012.2214766 pared with amorphous silicon makes it an excellent candidate for silicon-based multijunctions [2], [3]. Moreover, as a consequence of the abundance and nontoxicity of silicon, scaling up to the terawatt level will be possible in the near future. However, while initial efficiencies as high as $16.3 \%$ have been reported for thin-film silicon triple-junctions cells [4], the stabilized efficiency of modules and thus of the $\mu \mathrm{c}-\mathrm{Si}$ subcell has to be further improved for this technology to play a major role in clean and sustainable energy production.

Here, we focus on single-junction $\mathrm{p}-\mathrm{i}-\mathrm{n} \mu \mathrm{c}-\mathrm{Si}$ solar cells, where the intrinsic absorber layer quality is known to be crucial to obtain high-efficiency devices [5]-[7]. We notably investigate the role of porous material areas (often called cracks) that appear when challenging superstrate morphologies and/or inappropriate deposition conditions are used [8], [9]. We present an innovative 3-D tomographical reconstruction of a solar cell to evidence the 2-D network of these porous areas of defective material within the absorber layer when grown on highly textured superstrates.

Silicon-suboxide-doped layers have been proposed as excellent candidates to mitigate the effect of those localized porous zones [10]-[12]. We study here the role of these novel interfaces through variable illumination measurements (VIM) [13] and demonstrate the quenching of these defective areas when adequate interfaces are used. In addition, we present a postdeposition hydrogen plasma treatment allowing a significant improvement of the conversion efficiency, particularly when the solar cells are deposited on rough superstrates, and even when the best cell design is used. These new findings led us to outstanding single-junction microcrystalline devices, with a very high conversion efficiency of $10.9 \%\left(0.25 \mathrm{~cm}^{2}\right)$ and $10.4 \%$ $\left(1 \mathrm{~cm}^{2}\right)$.

\section{Cell Fabrication and Characterization}

Boron-doped zinc oxide ( $\mathrm{ZnO})$ obtained by low-pressure chemical vapor deposition (LPCVD) was used as front electrode directly deposited on top of AF45 Schott glass. The self-textured pyramidal surface morphology obtained with this LPCVD ZnO allows an efficient light trapping and, thus, a reduced thickness of the absorber layer [14]. The nominal thickness of the front $\mathrm{ZnO}$ was $4.5 \mu \mathrm{m}$ (Z5), with a typical sheet resistance of 9 $\Omega / \square$. The as-grown surface texture of LPCVD $\mathrm{ZnO}$ is excellent for efficient light harvesting but can be extremely challenging for the growth of high quality $\mu \mathrm{c}-\mathrm{Si}$, resulting in decreased 
electrical performance [15]-[17] and long-term stability issues when porous zones are present within the bulk material [18]-[20]. In order to overcome these effects, an argon-based plasma surface treatment can be used to improve the electrical performance $\left(V_{\mathrm{oc}}\right.$ and $\mathrm{FF}$ ) by smoothening the front electrode morphology, however, at the cost of current density loss [21]. Optimum treatment time on Z5 for single-junction microcrystalline silicon solar cell was determined to be about $45 \mathrm{~min}$.

Single-junction solar cells were deposited by plasmaenhanced chemical vapor deposition (PECVD) at a superstrate temperature of $200{ }^{\circ} \mathrm{C}$ and a pressure of 0.7 mbar. We varied both silane dilution $([\mathrm{SiH} 4] /[\mathrm{H} 2]=4-5 \%)$ and input power $\left(0.04-0.06 \mathrm{~W} / \mathrm{cm}^{2}\right)$ during the deposition of the intrinsic layer, in order to control the crystallinity (as measured by Raman spectroscopy) at the doped layers interfaces and within the absorber layer (typically 55-60\%). The excitation frequency was set at $70 \mathrm{MHz}$ and the deposition rate was $1.5-1.8 \AA / \mathrm{s}$, leading to typical initial cell efficiency of $9.5-10 \%$ for adequate cell design.

LPCVD ZnO films with thicknesses ranging between 2.5 and $5 \mu \mathrm{m}$ were used as back contact, depending on the experiment. The cells were patterned by liftoff and dry etching into 0.25 or $1-\mathrm{cm}^{2}$ areas. A dual-lamp sun simulator from Wacom under standard operating conditions (AM1.5g, $1000 \mathrm{~W} / \mathrm{m}^{2}, 25{ }^{\circ} \mathrm{C}$ ) was used for the measurements of the $I-V$ curves of solar cells, using gray filters for the VIM [13]. From these measurements, the open-circuit voltage $\left(V_{\mathrm{oc}}\right)$ and the fill factor $(\mathrm{FF})$ were deduced. The short-circuit density $J_{\mathrm{sc}}$ was calculated from external quantum efficiency (EQE) measurement, effectuated with a white dielectric back reflector. No antireflection coating was applied at the air-glass interface, except for the record devices in Fig. 6.

\section{TOMOGRAPHIC RECONSTRUCTION OF SOlAR CELlS}

A solar cell deposited on an as-grown rough superstrate (Z5) was investigated with focused ion beam (FIB) "slice and view" tomography [22], in order to further investigate $\mu \mathrm{c}-\mathrm{Si}$ microstructure on such a challenging superstrate and, more particularly, the creation of porous zones, which are commonly called "cracks." By milling to obtain a smooth cross section of the sample with an FIB column, then imaging the milled face with a scanning electron microscope (SEM) column, and after successively FIB milling back in steps of some nanometers, followed each time by SEM imaging, a 3-D dataset was created. A voxel size (i.e., 3-D pixel size) of $7 \times 7 \times 7 \mathrm{~nm}$ was used, recording the SEM images using an in-lens backscattered electron detector that gives mass contrast for the different layers (voids as dark regions), and grain contrast in the $\mathrm{ZnO}$, as seen in Fig. 1(a). It also minimizes the effect of "curtaining" from nanometer-scale undulations on the milled surface.

When considering a plane at the Z5/Si interface [see the green arrow in Fig. 1(a)], perpendicular to the $i$-layer growth direction, the 2-D network formed by the porous material can be seen directly.

Pseudocolor tomograms in Fig. 1(b) reveal the microstructure of cells codeposited on rough superstrate (Z5) and on a smooth

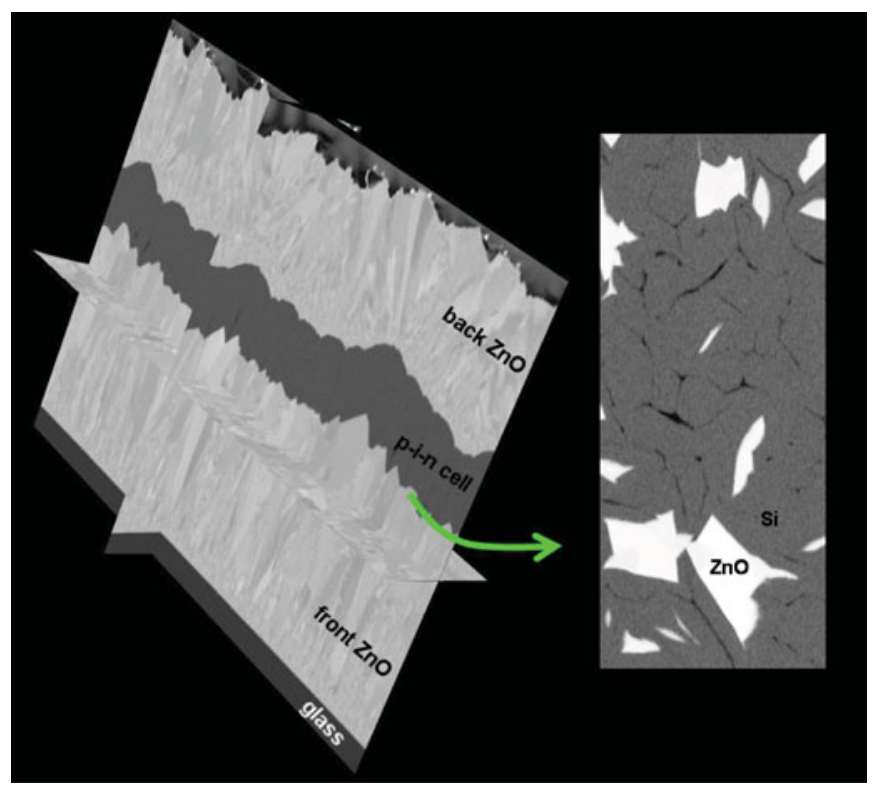

(a)

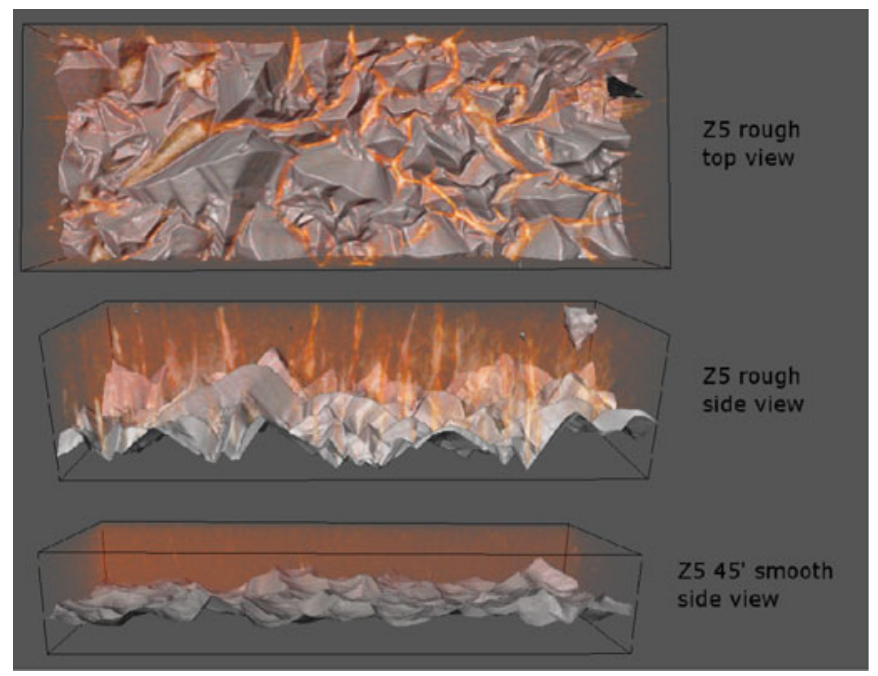

(b)

Fig. 1. (a) FIB tomography of a $\mu \mathrm{c}-\mathrm{Si}$ solar cell. A top view of the growth front in the reconstructed image at the $\mathrm{ZnO} / \mathrm{Si}$ interface (plane at the level of the green arrow, along the growth direction) reveals the 2-D porous network (black) in dense silicon (gray). The white areas are the top of the front $\mathrm{ZnO}$ pyramids. (b) Pseudocolor tomograms of the reconstructed network of porous zones (bright orange) in cells deposited on rough (Z5) and smooth (Z5 45') superstrates, respectively.

Z5 45' (current optimum superstrate). As expected from the standard 1-D image, cracks form a continuous porous network (bright orange) following the bottom of the valleys formed by the $\mathrm{ZnO}$ pyramids on rough superstrates. On the rough superstrate (Z5), this network is present throughout the absorber layer. In contrast with the smooth Z5 45', the porous zones are much smaller and no longer form a continuous network but are limited to a few zones of the upper part of the absorber layer.

Tomography thus appears as a valuable innovative technique to provide further insights into details of the $\mu \mathrm{c}-\mathrm{Si}$ microstructure, which are recognized to be an essential parameter for high-efficiency devices [9]. A high resilience to challenging 


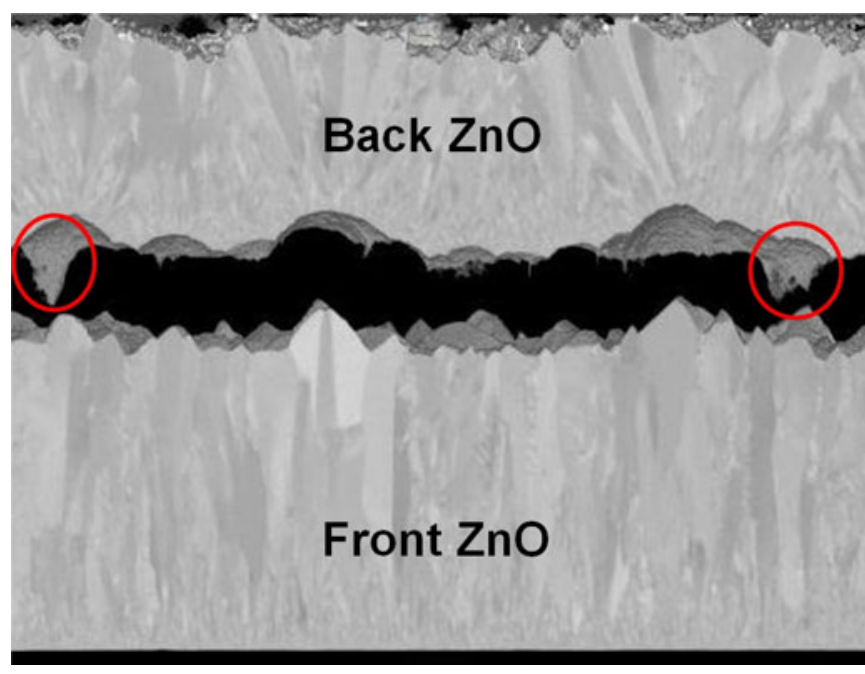

Fig. 2. Tomographic 3-D reconstruction of a single-junction $\mu \mathrm{c}$-Si solar cell deposited on a rough Z5 superstrate, where the silicon layer was filtered out. The potential pinching points can be seen, here filled with the $\mathrm{ZnO}$ back contact.

superstrate morphologies is of paramount importance when developing multijunctions devices, as additional phenomena such as pinching (defined as the creation of an increase of sharpness by the top cell grown by PECVD) can significantly change the properties of the $\mu \mathrm{c}-\mathrm{Si}$ bottom cell [23]. In that view, new insights could be gained by means of 3-D tomography, especially the localization and formation of potential pinching points related to the growth of thin-film silicon (see Fig. 2).

Tomographic reconstruction of complete solar cells thus opens new perspectives for detailed analysis of superstrate features on the growth of microcrystalline silicon material, even if instrumental and acquisition time demands render it inappropriate for routine diagnostics or high sample throughput analysis for materials development.

In the following section, we will demonstrate how the detrimental effect of such porous zones can further be reduced on rough superstrate, and especially the important role played by interfaces, well known to be one of the key parts in the development of high-efficiency microcrystalline solar cells [24]. We will then give a quantification of the beneficial effect of using silicon-oxide-doped layers $\left(\mathrm{SiO}_{x}\right.$ design $)$.

\section{Improvement of Cell Performance Using SILICON OXIDE DESIGN}

In Table I, a comparison of high-efficiency cells with standard design ( $\mu \mathrm{c}$-Si-doped layers) and silicon oxide design (nc-SiO doped layers) is shown. The cells are $1.6 \mu \mathrm{m}$ thick and were deposited on superstrates with decreasing roughness; going from Z5 treated 5' to the Z5 treated 45' that is currently our optimum superstrate for high-efficiency $\mu \mathrm{c}$-Si single-junction solar cells. Using silicon-oxide-doped layers, $V_{\mathrm{oc}}$ and FF were enhanced on all superstrates, and more remarkably on the roughest one.

At low illumination conditions (see Fig. 3), the benefit of the $\mathrm{SiO}_{x}$ design is obvious and consistent with [11], where quenching of local current drains was proposed as an explanation for the improved performance on rough superstrates. In-
TABLE I

Performance of Solar Cells as a Function of Superstrate TREATMent Time AND Doped LaYers Design, SHowing THE Benefit of THE $\mathrm{SIO}_{x}$ DESIGN

\begin{tabular}{|c|c|c|c|c|c|c|}
\hline & Superstrate & $\begin{array}{c}\mathrm{J}_{\mathrm{sc}} \\
{\left[\mathrm{mA} / \mathrm{cm}^{2}\right]}\end{array}$ & $\begin{array}{l}\mathrm{FF} \\
{[\%]}\end{array}$ & $\begin{array}{c}\mathrm{V}_{\mathrm{oc}} \\
{[\mathrm{mV}]}\end{array}$ & $\begin{array}{c}\eta \\
{[\%]}\end{array}$ & $\begin{array}{c}\mathrm{n} \\
{[-]}\end{array}$ \\
\hline \multirow{3}{*}{ Std } & Z5 5' & 23.9 & 67.2 & 493 & 7.9 & 1.8 \\
\hline & Z5 20' & 23.8 & 71.8 & 518 & 8.9 & 1.2 \\
\hline & Z5 45' & 23.1 & 74.4 & 529 & 9.1 & 1.1 \\
\hline \multirow{3}{*}{$\mathrm{SiO}_{\mathrm{x}}$} & Z5 5' & 25.5 & 69.0 & 512 & 9.0 & 1.4 \\
\hline & Z5 20' & 25.3 & 72.7 & 528 & 9.7 & 1.2 \\
\hline & Z5 45' & 24.6 & 74.5 & 543 & 10.0 & 1.1 \\
\hline
\end{tabular}

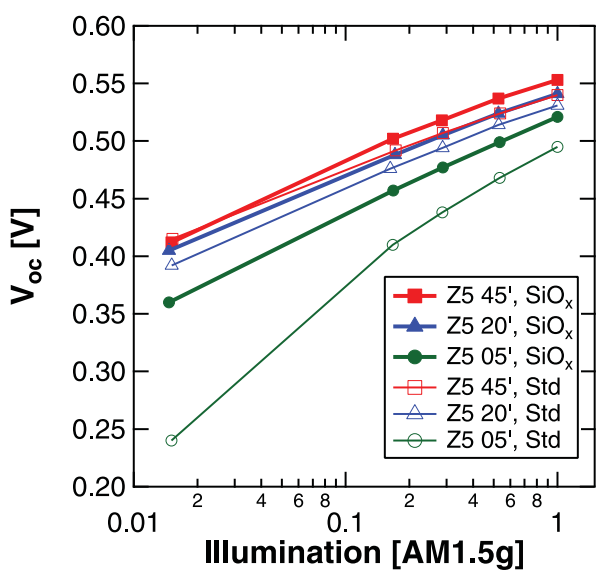

Fig. 3. $V_{\text {oc }}$ losses as function of illumination. $\mathrm{The}_{\mathrm{SiO}}$ design mitigates the detrimental effect coming from the porous zones. Similar behavior was observed in FF (not shown here).

TABLE II

InCREASE of the SOlar CELl PerformanCe After a Hydrogen Plasma POSTTREATMENT

\begin{tabular}{cccccc}
\hline \hline & & $\begin{array}{c}\mathrm{J}_{\mathrm{sc}} \\
{\left[\mathrm{mA} / \mathrm{cm}^{2}\right]}\end{array}$ & $\begin{array}{c}\mathrm{FF} \\
{[\%]}\end{array}$ & $\begin{array}{c}\mathrm{V}_{\mathrm{oc}} \\
{[\mathrm{mV}]}\end{array}$ & $\begin{array}{c}\eta \\
{[\%]}\end{array}$ \\
\hline \multirow{2}{*}{$\mathrm{Z5} \mathrm{20}{ }^{\prime}$} & $\mathrm{i}$ & 24.1 & 71.7 & 536 & 9.3 \\
& $\mathrm{pH}_{2}$ & 24.3 & 75.3 & 554 & $\mathbf{1 0 . 1}$ \\
\hline \multirow{2}{*}{$\mathrm{Z5} \mathrm{45}}$, & $\mathrm{i}$ & 23.5 & 73.6 & 552 & 9.5 \\
& $\mathrm{pH}_{2}$ & 23.7 & 75.4 & 561 & $\mathbf{1 0 . 0}$ \\
\hline \hline
\end{tabular}

deed, the value of the diode ideality factor $n$, as obtained by logarithmically fitting the $V_{\mathrm{oc}}$ versus illumination curves in Fig. 3 with a one-diode model, is decreased with $\mathrm{SiO}_{x}$ design and superstrate roughness, as can be seen in Table I.

The tomograms of Fig. 1 were performed on cells containing $\mathrm{SiO}_{x}$-doped layers. Those doped layers are, therefore, unlikely to have a significant effect on the appearance of porous zones during the deposition of the intrinsic layer when a rough superstrate is used. However, as described in [9], PECVD can indeed impact the porous zones density, especially by varying the hydrogen flow when going to higher deposition rates. Here, VIM on our samples thus demonstrate that a suitable choice of interfaces indeed mitigates the detrimental effect of porous zones on rough superstrates and permitted us to reach an efficiency of $9 \%$ on a very rough superstrate and $10 \%$ on our current optimal superstrate. 


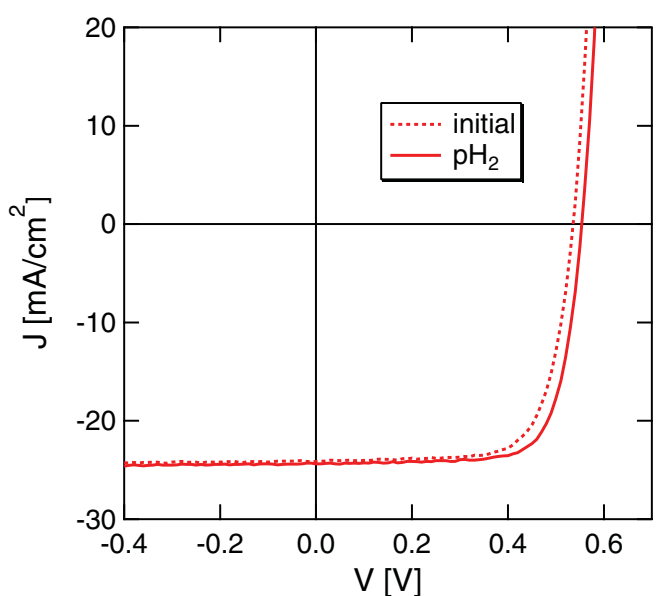

Fig. 4. $J-V$ curve of a cell deposited on medium-rough Z5 20', showing the beneficial effect of the $\mathrm{pH}_{2}$.

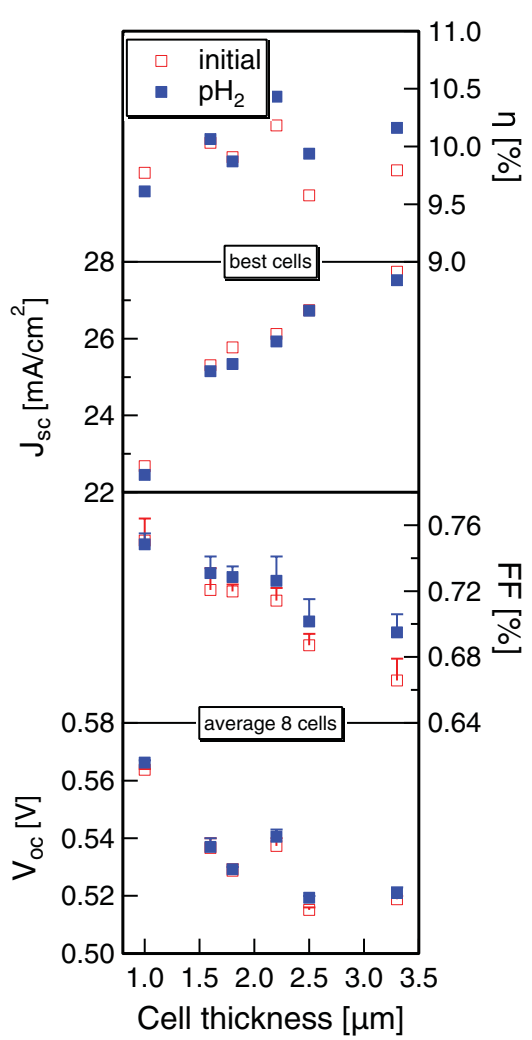

Fig. 5. Properties of solar cells deposited on smooth Z5 $45^{\prime}$ ' in initial state (red open squares) and after $\mathrm{pH}_{2}$ (blue solid squares), as a function of the cell total thickness. For $V_{\mathrm{Oc}}$ and FF, the values of the eight best cells on each superstrate are given (ranked by $V_{\mathrm{oc}} \cdot \mathrm{FF}$ ), while the error bars represent the value of the best cell for each thickness. The values of the best $V_{\mathrm{oc}}$ are not visible as they overlap with the average value. For the current densities and the efficiencies, only the best cells are given.

\section{Post-Deposition Treatment of the Solar Cells}

Recently, a hydrogen plasma treatment $\left(\mathrm{pH}_{2}\right)$ for the $\mathrm{ZnO}$ electrodes has been introduced in our laboratory [25]. Whereas such treatment increases the mobility and free carrier density of $\mathrm{ZnO}$ (leading to a decrease in its sheet resistance), to our knowledge, its effect had not yet been investigated on complete

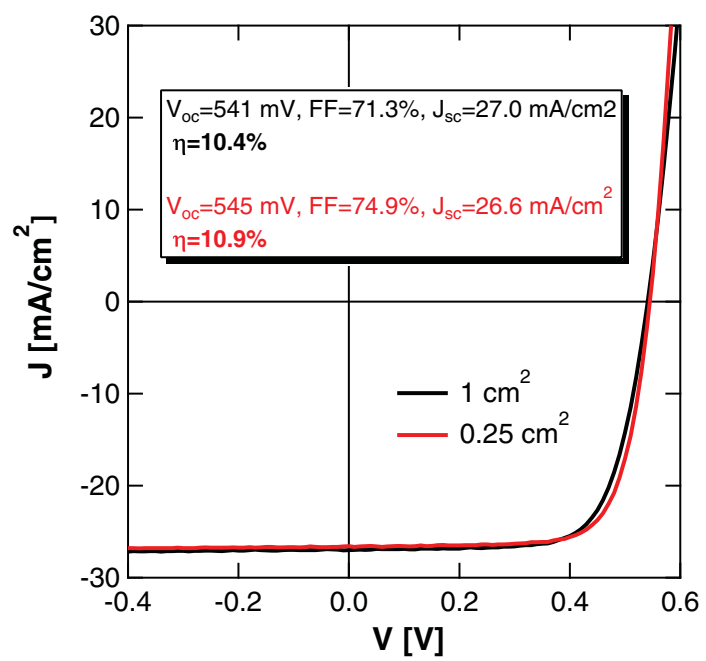

(a)

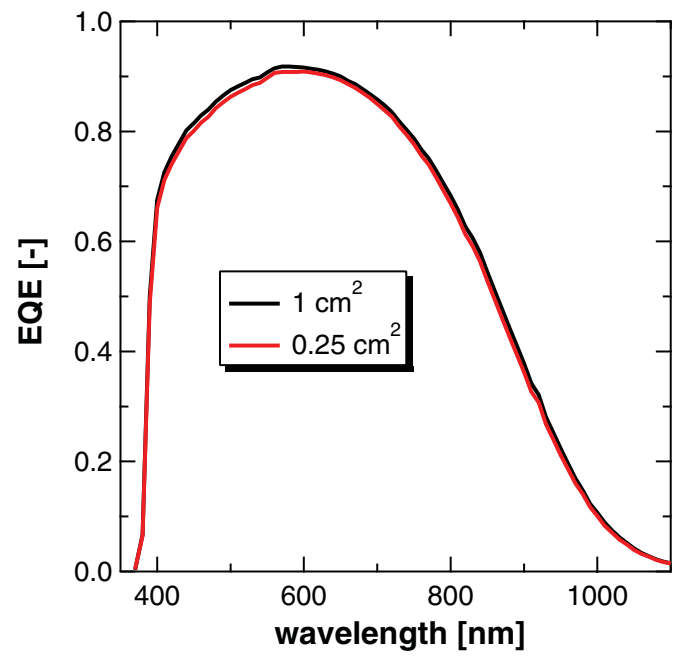

(b)

Fig. 6. $J-V$ curves and EQE of the best cells, with a total silicon thickness of $2 \mu \mathrm{m}$.

high-efficiency p-i-n microcrystalline solar cells. We applied the $\mathrm{pH}_{2}$ on finished (nonencapsulated) cells, in a PECVD reactor, at $200{ }^{\circ} \mathrm{C}, 0.5 \mathrm{mbar}$, with a power density of $0.15 \mathrm{~W} / \mathrm{cm}^{2}$, for 20 min.

Table II demonstrates the typical effect of the $\mathrm{pH}_{2}$ on $1.1-\mu \mathrm{m}$-thick solar cells $\left(0.25 \mathrm{~cm}^{2}\right)$ deposited on medium-rough Z5 20' and smooth Z5 45', with $\mathrm{SiO}_{x}$ design.

We observe, on the one hand, a reproducible improvement of up to $10 \mathrm{mV}$ in $V_{\mathrm{oc}}$ and 1-2\% (absolute) in FF for cells deposited on smooth Z5 $45^{\prime}$. On the other hand, the effect on $J_{\mathrm{sc}}$ is small $\left( \pm 0.2 \mathrm{~mA} / \mathrm{cm}^{2}\right)$. The gain is, moreover, more pronounced on rougher superstrates (up to $20 \mathrm{mV}$ in $V_{\mathrm{oc}}$ and $3.6 \%$ absolute in FF) such as the Z5 20' (see Fig. 4).

Whereas the gain in FF can partially be explained by a reduction of the sheet resistance of $\mathrm{ZnO}$, the strongly superstratedependent gain in $V_{\mathrm{oc}}$ is attributed to a change in the silicon material of the p-i-n device. We indeed suggest that the improvements of $V_{\text {oc }}$ and FF upon hydrogen plasma treatment are linked to a curing effect of porous zones, whose exact nature is 
still under investigation. Further experiments are now required to decouple thermal effects (e.g., by annealing under various atmospheres/vacuum) from those effects arising from the presence of hydrogen and of a plasma.

\section{Very High EFFICIENCY DEVICES}

The cell design concepts just discussed were then applied to various $i$-layer thicknesses of single-junction microcrystalline solar cells, ranging between 1 and $3.3 \mu \mathrm{m}$ (typical bottom cell thickness range used in tandems), while other layers were kept constant. The Raman crystalline fraction yielded $57 \pm 5 \%$ for all cells. The results of this thickness series on Z5 45' are shown in Fig. 5. Remarkably high conversion efficiencies between $9.5 \%$ and $10.5 \%$ were obtained, without a clear trend on the cell thickness: The decrease in $V_{\text {oc }}$ and FF observed when increasing the thickness of the cell is compensated by an equivalent increase of $J_{\mathrm{sc}}$.

With a recently developed antireflective texture at the airglass interface [26], we further obtained a $0.25-\mathrm{cm}^{2}$ cell with $10.9 \%$ efficiency, as well as a $1-\mathrm{cm}^{2}$ cell with $10.4 \%$ efficiency, lying amongst the highest efficiencies reported so far [27]. $J-V$ and EQE curves of these two cells are shown in Fig. 6.

Furthermore, the presently developed concepts also contributed to high-efficiency micromorph tandems, reaching $14.1 \%$ initial efficiency with a 290-nm-thick top cell [28].

\section{CONCLUSION}

We have demonstrated here the importance of both the cell design and the absorber layer microstructure in reaching highefficiency microcrystalline solar cells. Three-dimensional tomography appears as an innovative and valuable technique to further probe details of microcrystalline silicon microstructure, directly revealing the 2-D nature of the porous zones within the absorber layer. With VIM, we could show that their detrimental effect on solar cell performance could be reduced with appropriate cell design, such as the use of silicon suboxide layers. Furthermore, a hydrogen plasma post-deposition treatment allowed relative efficiency gains up to $5 \%$ on our best cells. All these developments permitted us to reach outstanding efficiencies for both 0.25 - and $1-\mathrm{cm}^{2}$ single-junction $(10.9 \%$ and $10.4 \%)$ and micromorph configurations (14.1\%).

\section{REFERENCES}

[1] Oerlikon Solar, Press rel., Jan. 16, 2012.

[2] J. Meier, R. Flückiger, H. Keppner, and A. Shah, "Complete microcrystalline p-i-n solar cell—Crystalline or amorphous cell behavior?," Appl. Phys. Lett., vol. 65, no. 7, pp. 860-862, 1994.

[3] K. Yamamoto, M. Yoshimi, Y. Tawada, Y. Okamoto, A. Nakajima, and S. Igari, "Thin-film poly-Si solar cells on glass substrate fabricated at low temperature," Appl. Phys. A, vol. 69, pp. 179-185, 1999.

[4] B. Yan, G. Yue, L. Sivec, J. Yang, S. Guha, and C.-S. Jiang, "Innovative dual function nc-SiOx:H layer leading to a $>16 \%$ efficient multi-junction thin-film silicon solar cell," Appl. Phys. Lett., vol. 99, pp. 113512-1113512-3, 2011.

[5] A. H. M. Smets, T. Matsui, and M. Kondo, "High-rate deposition of microcrystalline silicon p-i-n solar cells in the high pressure depletion regime," J. Appl. Phys., vol. 104, pp. 034508-1-034508-11, 2008.
[6] A. Gordijn, L. Hodakova, J. K. Rath, and R. E. I. Schropp, "Influence on cell performance of bulk defect density in microcrystalline silicon grown by VHF PECVD," J. Non-Cryst. Solids, vol. 352, pp. 1868-1871, 2006.

[7] O. Vetterl, A. Lambertz, A. Dasgupta, F. Finger, B. Rech, O. Kluth, and H. Wagner, "Thickness dependence of microcrystalline silicon solar cell properties," Sol. Energy Mater. Sol. Cells, vol. 66, pp. 345-351, 2001.

[8] H. Sakai, T. Yoshida, T. Hama, and Y. Ichikawa, "Effect of surface morphology of transparent electrode on the open-circuit voltage in aSi:H solar cells," Jpn. J. Appl. Phys., vol. 29, no. 4, pp. 630-635, 1990.

[9] G. Bugnon, G. Parascandolo, T. Söderström, P. Cuony, M. Despeisse, S. Hänni, J. Holovský, F. Meillaud, and C. Ballif, "A new view of microcrystalline silicon: The role of plasma processing in achieving a dense and stable absorber material for photovoltaic applications," Adv. Funct. Mater, vol. 22, pp. 3665-3671, 2012.

[10] P. Sichanugrist, T. Sasaki, A. Asano, Y. Ichikawa, and H. Sakai, "Amorphous silicon oxide and its application to metal/n-i-p/ITO type a-Si solar cells," Sol. Energy Mater. Sol. Cells, vol. 34, pp. 415-422, 1994.

[11] M. Despeisse, C. Battaglia, M. Boccard, G. Bugnon, M. Charrière, P. Cuony, S. Hänni, L. Löfgren, F. Meillaud, G. Parascandolo, T. Söderström, and C. Ballif, "Optimization of thin film silicon solar cells on highly textured substrates," Phys. Status Solidi A, vol. 208, no. 8, pp. 1863-1868, 2011.

[12] P. Cuony, D. T. L. Alexander, I. Perez-Wurfl, M. Despeisse, G. Bugnon, M. Boccard, T. Söderström, A. Hessler-Wyser, C. Hébert, and C. Ballif, "Silicon filaments in silicon oxide for next-generation photovoltaics," Adv. Mater, vol. 24, pp. 1182-1186, 2012.

[13] F. Meillaud, A. Shah, J. Bailat, E. Vallat-Sauvain, T. Roschek, B. Rech, D. Dominé, T. Söderström, M. Python, and C. Ballif, "Microcrystalline silicon solar cells: Theory and diagnostic tools," in Proc. 4th World Conf. Photovoltaic Energy Convers., May 2006, pp. 1572-1575.

[14] S. Faÿ, J. Steinhauser, S. Nicolay, and C. Ballif, "Polycrystalline ZnO:B grown by LPCVD as TCO for thin film silicon solar cells," Thin Solid Films, vol. 518, pp. 2961-2966, 2010.

[15] Y. Nasuno, M. Kondo, and A. Matsuda, "Effect of substrate surface morphology on microcrystalline solar cells," Jpn. J. Appl. Phys., vol. 40, pp. 303-305, 2001.

[16] M. Python, E. Vallat-Sauvain, J. Bailat, D. Dominé, L. Fesquet, A. Shah, and C. Ballif, "Relation between substrate surface morphology and microcrystalline silicon solar cell performance," J. Non-Cryst. Solids, vol. 354, pp. 2258-2262, 2008.

[17] H. B. T. Li, R. H. Franken, J. K. Rath, and R. E. I. Schropp, "Structural defects caused by a rough substrate and their influence on the performance of hydrogenated nano-crystalline silicon n-i-p solar cells," Sol. Energy Mater. Sol. Cells, vol. 93, pp. 338-349, 2009.

[18] S. Hänni, C. Battaglia, M. Boccard, G. Bugnon, P. Cuony, M. Despeisse, L. Ding, S. Nicolay, F. Meillaud, and C. Ballif, "Towards better understanding of long-term stability in thin film microcrystalline silicon solar cells," in Proc. 26th Eur. Photovoltaic Solar Energy Conf. Exhib., 2011, pp. 2699-2703.

[19] A. Bronneberg, A. H. M. Smets, M. Creatore, and M. C. M. van de Sanden, "On the oxidation mechanism of microcrystalline silicon thin films studied by Fourier transform infrared spectroscopy," J. Non-Cryst. Solids, vol. 357, pp. 884-887, 2011.

[20] T. Matsui, A. Matsuda, and M. Kondo, "High-rate microcrystalline silicon deposition for p-i-n junction solar cells," Sol. Energy Mater. Sol. Cells, vol. 90, pp. 3199-3204, 2006.

[21] M. Boccard, T. Söderström, P. Cuony, C. Battaglia, S. Hänni, S. Nicolay, L. Ding, M. Benkhaira, G. Bugnon, A. Billet, M. Charrière, F. Meillaud, M. Despeisse, and C. Ballif, "Optimization of $\mathrm{ZnO}$ front electrodes for high-efficiency micromorph thin-film Si solar cells," IEEE J. Photovoltaics, vol. 2, no. 3, pp. 229-235, Jul. 2012.

[22] M. Cantoni, C. Genoud, C. Hébert, and G. Knott, "Large volume, isotropic, 3D imaging of cell structure on the nanometer scale," Microsc. Analysis, vol. 24, no. 4, pp. 13-16, 2010.

[23] P. Cuony, M. Marending, D. T. L. Alexander, M. Boccard, G. Bugnon, M. Despeisse, and C. Ballif, "Mixed-phase p-type silicon oxide containing silicon nanocrystals and its role in thin-film silicon solar cells," Appl. Phys. Lett., vol. 97, pp. 213502-1-213502-3, 2010.

[24] Y. Mai, S. Klein, R. Carius, H. Stiebig, L. Houben, X. Geng, and F. Finger, "Improvement of open circuit voltage in microcrystalline silicon solar cells using hot wire buffer layers," J. Non-Cryst. Solids, vol. 352, pp. 1859$1862,2006$.

[25] L. Ding, M. Benkhaira, S. Nicolay, and C. Ballif, "Enhanced mobility of hydrogenated MO-LPCVD $\mathrm{ZnO}$ contacts for high performances thin film 
silicon solar cells," presented at the MRS Spring Meeting, Symp. A, San Francisco, CA, 2012.

[26] J. Escarré, K. Söderström, M. Despeisse, S. Nicolay, C. Battaglia, G. Bugnon, L. Ding, F. Meillaud, F.-J. Haug, and C. Ballif, "Geometric light trapping for high efficiency thin film silicon solar cells," Sol. Energy Mater. Sol. Cells, vol. 98, pp. 185-190, 2012.

[27] M. A. Green, K. Emery, Y. Hishikawa, W. Warta, and E. D. Dunlop, "Solar cell efficiency tables (version 39)," Progr. Photovoltaics Res. Appl. vol. 20, pp. 12-20, 2012.
[28] M. Boccard, C. Battaglia, S. Hänni, K. Söderström, J. Escarré, S. Nicolay, F. Meillaud, M. Despeisse, and C. Ballif, "Multiscale transparent electrode architecture for efficient light management and carrier collection in solar cells," Nano Lett., vol. 12, pp. 1344-1348, 2012.

Authors' photographs and biographies not available at the time of publication. 